\title{
Berardinelli-Seip Syndrome - A Case Report
}

\author{
Jana KAZANDJIEVA ${ }^{1}$, Dimitrina GULEVA ${ }^{1}$, Sonya MÁRINA ${ }^{1}$, \\ Assya NIKOLOVA ${ }^{1}$, Gergana MLADENOVA², Alexander KURTEV ${ }^{2}$ \\ ${ }^{1}$ Department of Dermatology and Venereology, Medical University of Sofia, Bulgaria \\ ${ }^{2}$ Specialized Hospital for Active Treatment in Pediatrics "Prof. Ivan Mitev", Medical University of Sofia, Bulgaria \\ *Correspondence: Dimitrina Guleva, E-mail: dimiguleva@gmail.com \\ DE GRUYTER
}

UDC 616-008-007.23:616.59

\begin{abstract}
Congenital generalized lipodystrophy (CGL), also known as Berardinelli-Seip syndrome (BSS), is a rare autosomal recessive disease characterized by near total absence of adipose tissue and muscular hypertrophy. Additional common clinical signs are acanthosis nigricans, acromegaloid features, hepatomegaly, hyperandrogenism, altered glucose intolerance, cardiomyopathy and hypertriglyceridemia. An 11-year-old girl was admitted to our Clinic presenting with hyperandrogenic features, generalized lack of adipose tissue, generalized muscular hypertrophy and brownish colored skin on the neck, axillas and inguinal folds associated with impaired glucose tolerance and hypertension. A clinical diagnosis of congenital generalized lipodystrophy was made.
\end{abstract}

\section{Key words}

Lipodystrophy, Congenital Generalized; Acanthosis Nigricans; Masculinity; Hypertrichosis; Signs and Symptoms; Case Reports

n 11-year-old girl was admitted to our Clinic for Athe first time for hypertrichosis mainly affecting the face and linea alba. In 2004, she was diagnosed with generalized lipodystrophy. Her symptoms included abdominal bloating, recurrent vomiting, reduced subcutaneous fat and prominent muscles. The girl was a normal full-term baby with no family history of genetic diseases or consanguinity.

Objectively, she was found to have dysmorphic features: male habitus, massive bone structure (Figures 1 and 2), strong and well-shaped muscles, big hands and feet, triangle face with rough features, rough voice, brownish thick skin on the neck, axillas and inguinal folds and hypertrihosis on the face and linea alba (Figures 3 and 4).

At the age of 11 her weight was $70 \mathrm{~kg}$, height $169 \mathrm{~cm}$, and BMI $-24.36 \mathrm{~kg} / \mathrm{m}^{2}$.

Laboratory reports showed high levels of triglycerides - $2.06 \mathrm{mmol} / \mathrm{l}$ (normal range $<1.7$ $\mathrm{mmol} / \mathrm{l}$ ), cholesterol $-5.3 \mathrm{mmol} / \mathrm{l}$ (normal range <
$5.2 \mathrm{mmol} / \mathrm{l}$ ), LDL - $4.66 \mathrm{mmol} / \mathrm{l}$ (normal range $<4.0$ $\mathrm{mmol} / \mathrm{l}$ ), VDRL - $1.14 \mathrm{mmol} / \mathrm{l}$ (up to $0.85 \mathrm{mmol} / \mathrm{l}$ ). The results of glucose tolerance tests were abnormal. Random blood sugar estimations at frequent intervals varied from 129 to $300 \mu \mathrm{IU} / \mathrm{ml}$. Complete blood count, urinalysis, liver function tests, electrolytes and hormonal status including TSH, follicle-stimulating hormone, luteinizing hormone, cortisol, growth hormone, estradiol, androstendione, dihydroepiandrostendione, C-peptide were within normal limits.

Cytogenetic analysis showed $46 \mathrm{XX}-$ a normal female karyotype without numerical or structural aberrations. According to the medical history, the genetic analysis performed in 2004, showed that the patient had Berardinelli-Seip syndrome (BSS), subgroup 1.

The X-ray of the right wrist revealed a bone age corresponding with the age of 14,5 years, and a "closed" sella turcica. The ultrasound findings were normal, except for a fatty liver. 


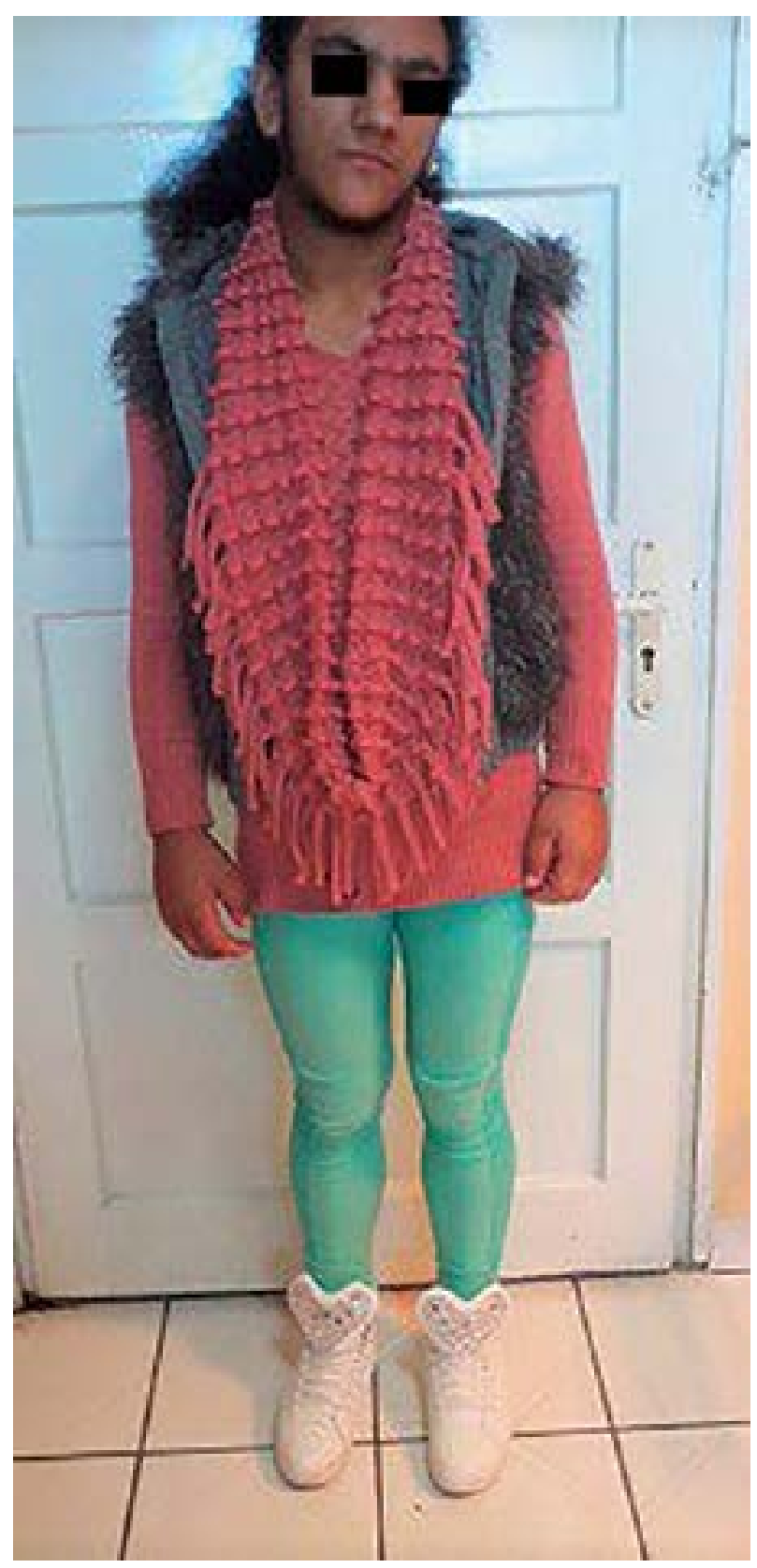

Figure 1. 11- year-old girl with male habitus, massive bone structure, strong and well-shaped muscles

Cardiac examination showed a normal status of the lungs, but also left ventricular hypertrophy, hypertension $(142 / 89 \mathrm{~mm} \mathrm{Hg})$, and heart rate between 97 and $131 \mathrm{bpm}$. Gynecological examination revealed moderate hypertrophy of the clitoris and hypoplastic uterus. No neurological abnormalities, hepatosplenomegaly or renal disorders were found. The patient was examined by a psychologist who established

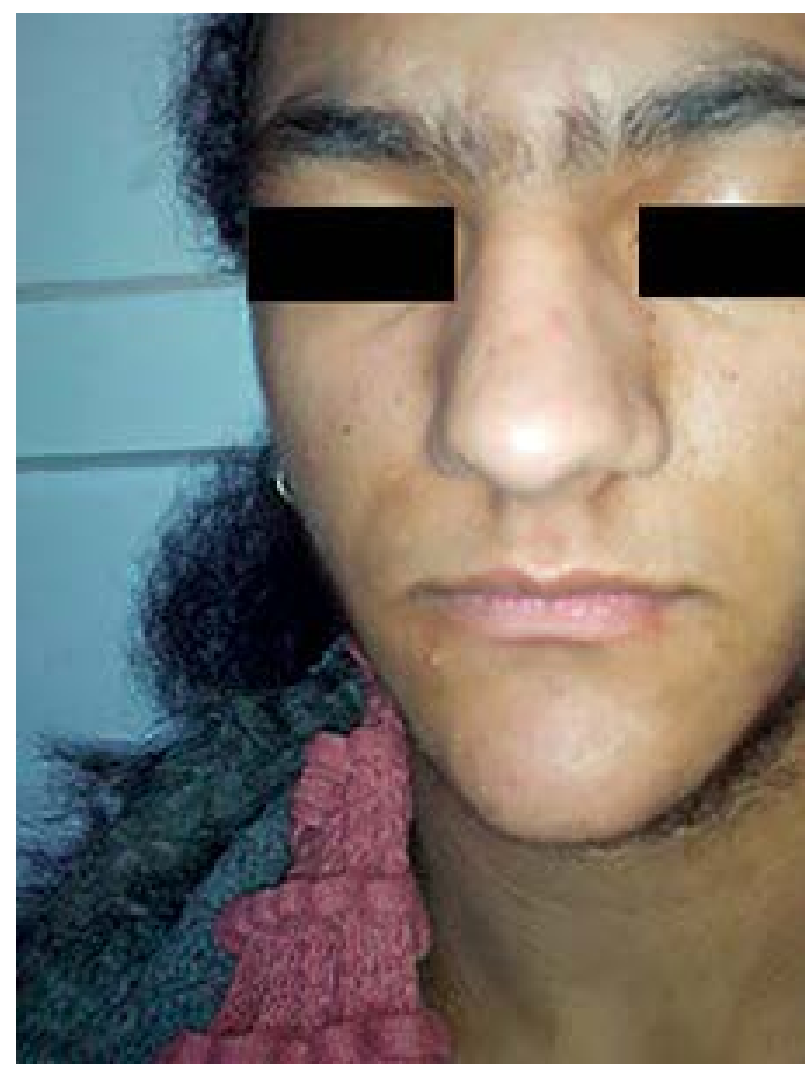

Figure 2. Typical features in Berardinelli-Seip Syndrome -triangle face, rough features and hypertrihosis on the face

a mental deficiency (IQ 88), inhibited behavior, low self-esteem, and poor social maturity.

The initial treatment, including $0.9 \% \mathrm{NaCl}$ $500 \mathrm{mg}$ infusions and glucose $75 \mathrm{~g}$, lasted for a week. Thereafter, metformin hydrochloride, a subclinical dose of $500 \mathrm{mg} /$ day was administered. Later on, the therapy was increased gradually, up to $2550 \mathrm{mg} /$ day $(850 \mathrm{mg}$ three times a day). A fat-restricted diet (20\%-30\% fat intake) was initiated. Laser removal of the excess hair on the face was recommended.

\section{Discussion}

Lipodystrophies are a group of metabolic disorders characterized by varying degrees of adipose tissue loss (1). They are characterized by absence of adipocytes thus relating to accumulation of lipids in the muscles, liver and other areas of the body (2). Lipodystrophies are often associated with metabolic complications such as diabetes mellitus, hypertriglyceridemia and hepatic steatosis $(3,4)$. They can be classified into 3 groups - 


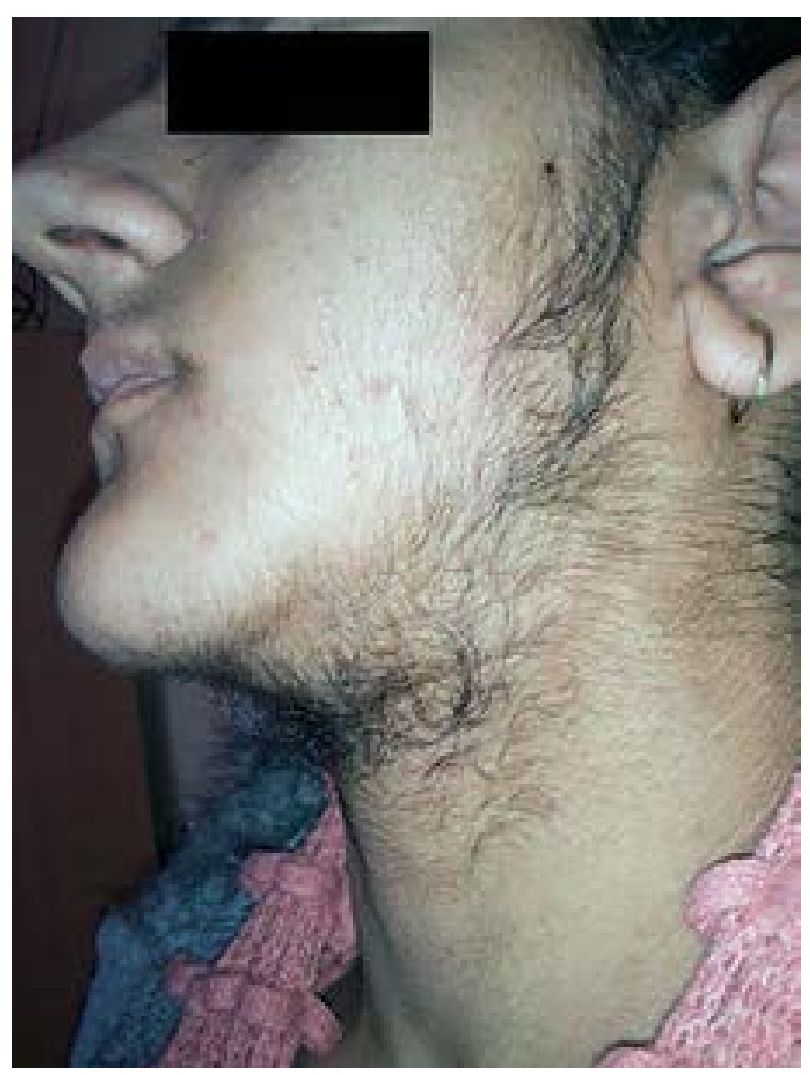

Figure 3. Hypertrihosis on the face in 11-year-old girl (left side)

generalized, partial and local, depending on the degree and localization of fat loss. The first two groups are divided into 2 types - inherited and acquired.

Berardinelli-Seip syndrome is an autosomal recessive disease of a generalized type lipodystrophy with a worldwide prevalence of 0.2:100.000 (5). BSS is mainly found in Lebanon, Portugal, Norway and USA, as well as in a few Asian, African and Brazilian families $(6,7,8)$. The disease was first described by Berardinelli in 1954 (9) and by Seip in 1959 (10). CGL is linked mainly to AGPAT2 (BSS type 1) and BSCL2 (BSS type 2) genes and rarely to CAV1 and PTRF genes. It is believed that type 1 is less severe than type 2 . The sex ratio is 1:1. Van Maldergern et al. (11) reported an excess of females with AGPAT2 mutations and an excess of males with seipin mutations. According to the same author, females have a more severe disease course.

Manifestations and major findings are generalized lack of adipose tissue, insulin-resistant diabetes without ketoacidosis, hypertrygliceridemia, and hepatosplenomegaly. Other features include genera-

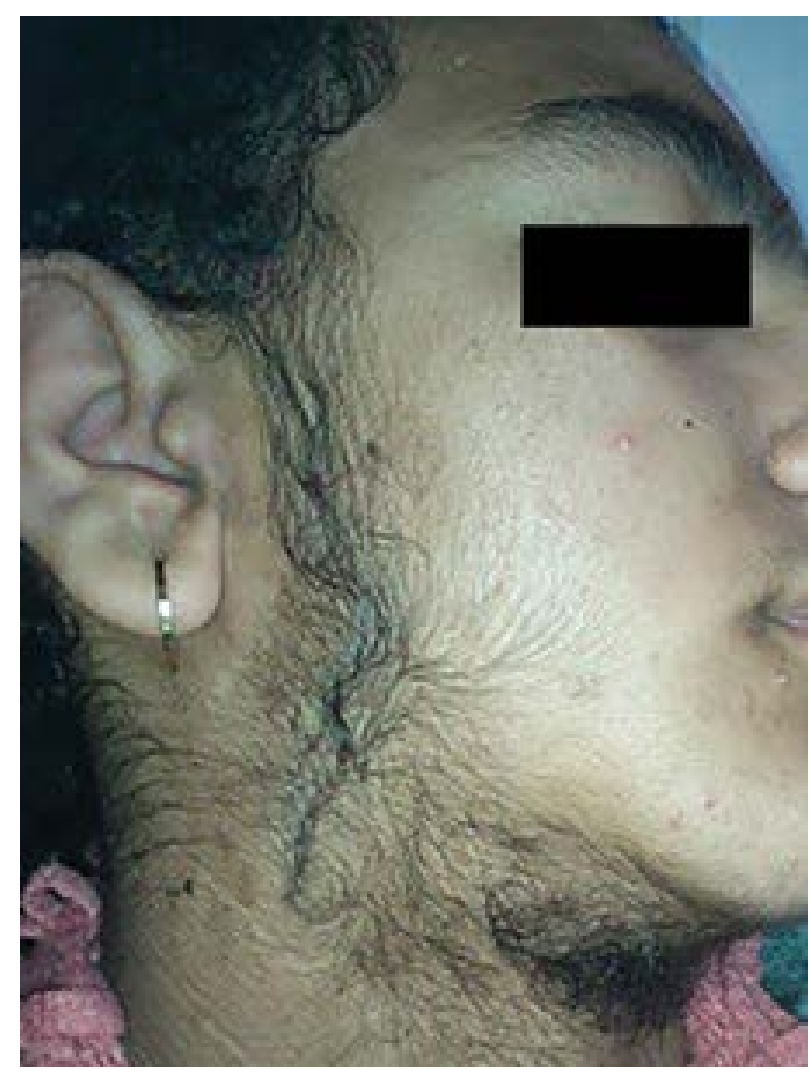

Figure 4. Hypertrihosis on the face in 11-year-old girl (right side)

lized muscular hypertrophy, prominent ears, acanthosis nigricans, hypertrichosis, thick curly scalp hair, hypertension, sometimes - corneal opacities, elevated metabolic rate, cutaneous xanthomas (12) and mental retardation in $50 \%$ of cases (13).

To date there are approximately 300 reported cases in which patients are virtually completely without body fat $(7,8,14)$.

CGL is difficult to treat, but insulin therapy, lipidlowering drugs and moderate calorie restrictions $(20 \%$ $30 \%)$ are recommended. A new, therapeutically effective, long-term option for severe forms of lipodystrophy, is leptin - adipocyte hormone which may improve the insulin resistance, dyslipidemia and hepatic steatosis, characteristic for patients with BSS $(15,16)$.

\section{Conclusion}

We present a rare case of BSS type 1 with characteristic features of "masculine look" with generalized lack of subcutaneous tissue, muscular hypertrophy, acanthosis nigricans and hypertrichosis associated with 
impaired glucose tolerance, hypertrygliceridemia and hypertension.

\section{Abbreviations:}

CGL - Congenital generalized lipodystrophy

BSS - Berardinelli-Seip syndrome

\section{References}

1. Garg A, Agarwal AK. Lipodystrophies: disorders of adipose tissue biology. Biochim Biophys Acta. 2009;1791(6):507-3.

2. Nolis T. Exploring the pathophysiology behind the more common genetic and acquired lipodystrophies. J Hum Genet. 2014;59(1):16-23.

3. Abate N. Adipocyte maturation arrest: a determinant of systemic insulin resistance to glucose disposal. J Clin Endocrinol Metab. 2012;97(3):760-3.

4. Bertrand AT, Chikhaoui K, Ben Yaou R, Bonne G. [Laminopathies: one gene, several diseases]. Biol Aujourdhui. 2011;205(3):147-62.

5. Bissonnette B, Luginbuehl I, Marciniak B, Dalens B. Syndromes: rapid recognition and perioperative imlications. New York: McGraw-Hill; 2006.

6. Magre J, Delepine M, Khallouf E, Gedde-Dahl T Jr, Van Maldergem L, Sobel E, et al. Identification of the gene altered in Berardinelli-Seip congenital lipodystrophy on chromosome 11q13. Nat Genet. 2001;28(4):365-70.

7. Magre J, Delepine M, Van Maldergem L, Robert JJ, Maassen JA, Meiser M, et al. Prevalence of mutations in AGPAT2 among human lipodystrophies. Diabetes. 2003;52(6):1573-8.
8. Agarwal AK, Simha V, Oral EA, Moran SA, Gorden P, $\mathrm{O}^{`}$ Rahilly $\mathrm{S}$, et al. Phenotypic and genetic heterogenecity in congenital generalized lipodystrophy. J Clin Endocrinol Metab. 2003;88(10):4840-7.

9. Berardinelli W. An undiagnosed endocrinometabolic syndrome: report of 2 cases. J Clin Endocrinol Metab. 1954;14(2):3390-4.

10.Seip M. Lipodystrophy and gigantism with associated endocrine manifestations: a new diencephalic syndrome? Acta Pediatr. 1959;48:555-74.

11.Van Maldergem L, Magre J, Khallouf TE, Gedde-Dahl T Jr, Delepine M, Trygstad O, et al. Genotype-phenotype relationships in Berardinelli-Seip congenital lipodystrophy. J Med Genet. 2002;39(10):722-33.

12.Roth DE, Schikler KN, Callen JP. Annular atrophic connective tissue panniculitis of the ankles. J Am Acad Dermatol. 1989;21(5 Pt 2):1152-6.

13. Bennett T, Allford M. Delayed emergence from anesthesia in a child with congenital generalized lipodystrophy (BerardinelliSeip syndrome). Paediatr Anaesth. 2012;22(3):298-313.

14.Pardini VC, Victoria IM, Rocha SM, Andrade DG, Rocha AM, Pieroni FB, et al. Leptin levels, beta-cell function, and insulin sensitivity in families with congenital and acquired generalized lipoatropic diabetes. J Clin Endocrinol Metab. 1998;83(2):503-8.

15.Moran SA, Patten N, Young JR, Cochran E, Sebring N, Reynolds J, et al. Changes in body composition in patients with severe lipodystrophy after leptin replacement therapy. Metabolism. 2004;53(4):513-9.

16. Gorden P, Gavrilova O. The clinical uses of leptin. Curr Opin Pharmacol. 2003;3(6):655-9.

\section{Berardineli-Sip sindrom - prikaz slučaja}

\section{Sažetak}

Kongenitalna generalizovana lipodistrofija, poznata i kao Berardineli-Sip sindrom, je retka autozomna recesivna bolest koju karakteriše potpuno odsustvo masnog tkiva i mišićna hipertrofija. Osim ovih, prisutni su i drugi klinički znaci kao što su: akantoza, akromegalija, hepatomegalija, hiperandrogenizam, poremećaj tolerancije na glukozu, kardiomiopatija i hipertrigliceridemija. Jedanaesto- godišnja devojčica primljena je na Kliniku sa hiperandrogenim karakteristikama, generalizovanim nedostatkom masnog tkiva, generalizovanom mišićnom hipertrofijom, braonkastom bojom kože na vratu, ispod pazuha i predelu prepona, poremećajem tolerancije na glukoze i hipertenzijom. Postavljena je dijagnoza kongenitalne generalizovane lipodistrofije.

\section{Ključne reči}

Kongenitalna generalizovana lipodistrofija; Akantoza nigrikans; Muški habitus; Hipertrihoza; Znaci i simptomi; Prikazi slučajeva 